UNNES

\title{
The Effectiveness of Role Playing Method in Learning Immune System Material on the Creativity and Learning Outcomes of High School Students
}

\author{
Armi Nuridah $^{1 凶}$ Partaya $^{1}$
}

Biology Department, FMIPA, Universitas Negeri Semarang, Indonesia

\begin{tabular}{l} 
Info Article \\
\hline History Article: \\
Received: September 2019 \\
Accepted: October 2019 \\
Published: December 2019 \\
\hline Keywords: \\
Creativity, Learning outcomes, \\
Role playing, \\
\hline
\end{tabular}

Role playing,

\begin{abstract}
The problem that occurs in the education world right now is the low learning outcomes and student creativity. Based on references, the roles playing method is an effective learning method for increasing student creativity and learning outcomes. The aim of this study is to determine the effectiveness of the roles playing method on creativity and student learning outcomes and to find out the effectiveness of the roles playing method on learning the immune system. This research is a quasi-experimental research with nonequivalent control group design. The population are all students of grade 11 in MIA MAN 2 Semarang 2018/2019 school year. The sample is determined by purposive sampling and 2 classes have selected as the experimental class and the control class. In this study the experimental class carried out immune system learning using the roles playing method while the control class used the lecture method. The results showed that $85.56 \%$ of the experimental class students has creativity with creative to very creative categories while the control class is only $41.67 \%$ of students included in the creative and very creative categories. Student learning outcomes data show that the classical learning completeness of the experimental class is higher than the control class with a difference of $36.12 \%$. The average value of learning outcomes and the average $\mathrm{N}$-Gain score of the experimental class students also have a higher average value of the control class. The implementation of learning the roles playing method average $\mathrm{N}$-gained a score of 0,62 . Based on the description it can be concluded that the role playing method is effective on the creativity and learning outcomes of high school students and it can be concluded that the role playing method is effectively applied to learning the immune system because the results of the study already meet all the indicators that have been set.
\end{abstract}

(C) 2019 Universitas Negeri Semarang

$\triangle$ Address Correspondence:

Building D6 Lt.1 J1 Raya Sekaran Gunungpati Semarang

p-ISSN 2252-6579

E-mail: arminur12@gmail.com

e-ISSN 2540-833X 


\section{INTRODUCTION}

A common problem in the learning process at schools lately is the students low understanding that shown by students learning outcomes who are still under the Minimum Mastery Criteria (KKM) (Adiba et al., 2018). Based on the results of an interview with one of the teachers of biology at MAN 2 Semarang, it is known that as many as $50 \%$ of students grade XI have a daily test score that is still under the KKM. One of them is the material of the immune system. This indicates that student learning outcomes are not optimal and accordance with the expected goals.

According to Nurfaidah et al. (2018) one of the factors that causes learning outcomes that are not optimal is the use of learning methods that have not varied. Jayanti et al., (2017) explained that the learning of curriculum 2013 emphasizes active learning and student-centered (student centered learning). However, in the facts showed that learning process in the schools is still dominated by the use of traditional methods which inclined to be teacher centered. Rianto (2006) explained the traditional method can be used to explain a lot of material in a short time, but it also has many shortage such as the learning process is dominated by the teacher, so the students become passive and inclined to memorize the material so that the concept of the material cannot be remembered for a long time and in the end, that method will reduce the creativity of students.

The results of Global Creativity Index research the year 2015 put Indonesia's creativity ranked 115 out of 139 countries in the world. This shows that the creativity of the Indonesian people is still relatively low. The facts show that creativity is a thing that is still lacking attention in the learning process at school. According to Munandar (2009) the creativity of someone can be seen based on the aptitude characteristics (creative thingking) and non-aptitude characteristics (creative attitude). Non-aptitude characteristics (creative attitude) of students consists of four aspects namely curiosity, imaginative nature, like challenges and have bravely to take the risks. The results of observations at MAN 2 Semarang showed that students were less active in asking questions, students still had difficulty understanding abstract material such as the immune system material, students were less enthusiastic about learning of biology subject and lack of student participation in discussion activities. This shows that student behavior has not displayed a creative attitude.

In this modern era, the need of creativity is become very important. The challenges in various aspect of life required many creativity to provide the problem solving. Creativity is one of the curriculum 2013 goals that is important to develop in the schools. According to the Act of Republic Indonesia Number 20 The Year 2003 Article 3 stated that National Education aims to develop the potential of students become people of faith, piety, knowledgeable, capable, creative, independent and become democratic and responsible citizens. The progress of science and technology in various fields is an example of the results of human creativity. Creativity will bring up many new ideas to solve existing problems. Therefore, workforce who has creative abilities are needed in this era. The high needs for creative workforce encourages the schools as a National Educational Institution to creat a creative nation generation so they can contribute in advancing the nation's civilization.

Based on these problems, it is necessary to apply an effective learning method to increase creativity and student learning outcomes. Sutiyani et al. (2015) stated that the use of the role playing method can make it easier for students to analogize the processes that occur in the body by acting through drama. The advantages of the role playing method are as follows: 1) it can impress strongly and longlasting in students' memories, 2) role playing is very attractive to students, thus enabling the class to be dynamic and full of enthusiasm, 3) it can arouse passion and optimism, 4) it can train students to take the initiative and be creative and 5) it can explore the imagination of students (Djamarah \& Zain, 2002, Sudjana, $2009 \&$ Khoerunnisa, 2015).

Cracium's research results (2010) shows that the role playing method is able to develop skills and abilities such as responsibility, leadership, working group, and creative in problem solving. Oriza (2018) in his research has also concluded that the role playing method is an effective method for increasing the 
creativity of young children. Research conducted by Anggraeni (2015) has also proven that effective and assisted medical role playing methods are used to improve learning outcomes in high school student on reproductive system material. Sutiyani (2015) also agreed that role playing methodcan improve learning outcomes on the theme of global warming and it is impact on the environment. Thus, it is expected that the application of the role playing method can be effective to train creativity and improve student learning outcomes MAN 2 Semarang.

Based on the background above, the writer is interested to conduct the research entitled "The Effectiveness of the Role playing Method in Learning Immune System Material on the Creativity and Learning Outcomes of Senior High School Students". According to Maulana \& Rachman (2016) Effectiveness is the ability of a unit to achieve the goal have been set. Therefore, effectiveness in this research can be interpreted as a condition that indicates the level of success or achievement of aims that are measured in accordance with the aims that have been planned previously. Those aims in this research namely: (1) to determine the effectiveness of the role playing method in learning the immune system material on the creativity of Senior High School students, (2) to determine the effectiveness of the role playing method in learning the immune system material on the learning outcomes of Senior High School students and (3) to know the effectiveness of role playing that is applied to learning the immune system.

\section{RESEARCH METHOD}

This research is quasi-experimental research with non-equivalent control group design. The population in this study is all students of class XI MIA MAN 2 Semarang 2018/2019 academic year. The sample is determined by purposive sampling and 2 classes are selected as the experimental class and the control class. In this study, the experimental class carried out immune system learning using the role playing method while the control class used the lecture method. The taken research data are student creativity, student learning outcomes, and implementation of the role playing learning. The student creativity data obtains by the questionnaire method, while learning outcome data obtained by the test method while the data on the implementation of role playing learning obtained by the observation method. Student creativity data were analyzed descriptively, while learning outcomes were analyzed with $\mathrm{n}$ gain. The relationship between the role playing method and student creativity, and test results between role playing method and student learning outcomes were analized Pearson Correlation

\section{RESULTS AND DISCUSSION}

Effectiveness of role playing method in learning materials of the immune system on the creativity and learning outcomes of high school students measured by the following indicators: 1) the number of students classified as creative and very creative in the experimental class is more than in the control class, 2) as much as $\geq 75 \%$ experimental class students are classified as creative and very creative criteria, 3) the classical completeness of the experimental class is higher than the control class 4) the learning outcomes of the experimental class students have a higher average score than the control class 5) the average N-gain score in the experimental class is higher than the control class. 6) the implementation of the role playing method learning have scores $\geq 85 \%$

\section{Students' Creativity}

Student creativity data in this study are obtained from student creativity questionnaires that are filled out by all students of the experimental class and the control class. The results of the creativity analysis of the experimental class and control class students are presented in Table 1. 
Table 1 The results of student creativity in the experimental and control class

\begin{tabular}{lcccc}
\hline \multirow{2}{*}{ Criteria } & \multicolumn{2}{c}{ Experimental class } & \multicolumn{2}{c}{ Control class } \\
\cline { 2 - 5 } & Number of students & Percentage $(\%)$ & Number of students & Percentage $(\%)$ \\
\hline Very creative & 6 & 16,67 & 0 & 0 \\
Creative & 23 & 63,89 & 15 & 41,67 \\
Quite creative & 9 & 25 & 21 & 58,34 \\
Less creative & 0 & 0 & 0 & 0 \\
Very less creative & 0 & 0 & 0 & 0 \\
\hline
\end{tabular}

Table 1 shows that as many as 29 students (80.56\%) of the experimental class had creativity with creative to very creative categories while the control class only amounted to 15 children (41.67\%) included in the creative category and none of the students is classified as very creative. Based on Table 1, the application of the role playing method in learning the immune system is more effective for training student creativity compared to the lecture method. This is because these results meet the two established indicators, such as: (1) the number of students classified as creative and highly creative in the experimental class is greater than in the control class and (2) as much as $\geq 75 \%$ of the experimental class students are classified as creative criteria and very creative.

The results of the study are followed by a correlation test to determine the relationship between the role playing method and student creativity. The results of the correlation test between the role playing method and student creativity are presented in Table 2 .

Table 2 Correlation test results between the role playing method and student creativity

\begin{tabular}{llrr}
\hline & & Role Playing Method & Creativity \\
\hline Role Playing Method & Pearson Correlation & 1 & 0,429 \\
& Sig. (2-tailed) & & 0,009 \\
& N & 36 & 36 \\
\hline Creativity & Pearson Correlation & 0,429 & 1 \\
& Sig. (2-tailed) & 0,009 & 36 \\
& N & 36 & \\
\hline
\end{tabular}

The correlation test results in Table 2 show that between the role playing method and student creativity are positively correlated with the correlation number 0.429 . This means that the higher the students' responses to role playing learning, the more they will improve their creativity. The response questionnaire contained several statements that showed the students ' responses after applying the role playing method to several aspects, they are learning interest, student interest, learning atmosphere, learning experience, students' understanding of the material, curiosity, imaginative nature, challenges, and aspects of the courage to take the risk. So, if the score of the responses obtained is getting better, it can be interpreted that the student follows the role playing learning well so that the more spurs these students to develop their creativity. Score 0.429 indicates that both variables have a moderate level of correlation because they are in the range of 0.40 to 0.599 (Sugiyono 2007, referred to in Priyatno 2010). So the results of this test show that the role playing method and student creativity are positively correlated with moderate correlation and both of them have a significant relationship.

Role playing is one form of active learning that involves students directly in the process of playing roles. This involvement makes role playing learning more interesting and enjoyable, thereby increasing students' interest in participating in learning activities. Students look very enthusiastic when preparing the role playing. This method is the first method applied in learning biology in this school so that students have a high curiosity. This method provides a place for all students to explore their imagination and put it into role playing activities carried out in groups in front of the class. A variety of students' imaginations are shown in their appearance so that they can portray characters with various dialogues, expressions, improvisations, costumes and equipment that are in accordance with the character being played. The existence of these challenges then encourages students to like challenges. In role playing learning, there are also stages of evaluation and discussion that provide space for students to express opinions, provide criticism, and accept criticism from others. It trains students to take risks that are by accepting criticism and 
expressing opinions. Curiosity, imaginative nature, like challenges and dare to take risks are characteristics that show students' non-aptitude creativity.

The results of this study indicate that the role playing method is effective for training the creativity of high school students. The results of this study are consistent with the results of Baroroh's (2011) study which explains that the role playing method can increase students' creative values by $19.6 \%$. Oriza's research results (2016) also show that the role playing method is effective to increase creativity to increase the creativity of Early Childhood in Al Khairiyah Kindergarten Labuhan Ratu Bandar Lampung. This is also in line with the explanation of Rumilasari et al. (2016) that the role playing method is able to increase creativity, self-confidence, social abilities, and empathy.

\section{Students' Learning Outcomes}

Student learning outcomes in the experimental class after implementing immune system learning using the role playing method and the control class with the lecture method are presented in Table 3.

Tabel 3 Students' learning outcomes in experimental class and control class

\begin{tabular}{|c|c|c|}
\hline Source of Variation & Experimental class & Control class \\
\hline Number of Students & 36 & 36 \\
\hline High score & 90 & 85 \\
\hline Lowest score & 55 & 50 \\
\hline Average learning outcomes & 74,17 & 65,83 \\
\hline Number of student that pass & 22 & 9 \\
\hline Number of student that do not pass & 14 & 26 \\
\hline Classical completeness & $611,12 \%$ & $25 \%$ \\
\hline Average N-Gain score & 0.62 & 0,49 \\
\hline Normality test result & 0,067 & 0,056 \\
\hline Homogenity test result & & \\
\hline Independent samples t-test result & & \\
\hline
\end{tabular}

The results of this study are complemented by the results of the correlation test between the role playing method and student learning outcomes shown in Table 4.

Table 4 Correlation test results between role playing method and student learning outcomes

\begin{tabular}{llrr}
\hline & & Role Playing Method & Learning Outcomes \\
\hline Role Playing Method & Pearson Correlation & 1 & $-0,219$ \\
& Sig. (2-tailed) & 36 & 0,199 \\
& $\mathrm{~N}$ & $-0,219$ & 36 \\
\hline Learning Outcomes & Pearson Correlation & 0,199 & 1 \\
& Sig. (2-tailed) & 36 & 36 \\
& $\mathrm{~N}$ & & \\
\end{tabular}

Based on the analysis of the average learning outcomes, classical completeness and N-Gain test results indicate that the role playing method in this study is effective against student learning outcomes because it meets all the indicators that have been set which are: 1) classical completeness of the experimental class is higher than the control class, 2) the learning outcomes of the experimental class students had higher average scores than the control class, 3) the average N-Gain score in the experimental class is higher than the control class.

The application of the role playing method is effective to improving student learning outcomes because these methods make students gain direct learning experiences so that learning becomes more meaningful. The involvement is shown by the participation of all students in the role playing activities that is demonstrated in turn by each group. The role playing scenario contains material about the immune system, namely the non-specific immune system, the specific immune system, immunizations, and immune system disorders. Through these role playing activities, the immune system material that is abstract 
becomes easier to understand because students play their own material concepts. The role playing activities will make students gain direct experience in learning so that the material learned can be remembered longer (Alfianto 2015). Learning in the control class that applies the lecture method tends to make students passive because students are not directly involved in the learning process. This is evidenced by the classical completeness results of the experimental class which reaches $61.12 \%$, while the control class is only $25 \%$. The results of the Independent sample t-test also showed that the learning outcomes of the experimental and control class are significantly different and the experimental class had higher learning outcomes than the control class. N-gain test results also indicate that the experimental class has an average $\mathrm{N}$-gain higher than the control class.

The application of the role playing method also creates a pleasant, interesting learning atmosphere, and increases students' interest in learning to continue to follow the learning process. Role playing is a learning method that is packaged in the form of a game so that it is more fun. This is in accordance with the explanation of Sutiyani (2015) that the method of learning role playing is one of the models that highlight learning that is fun and can activate students. Fun learning encourages students to be more interested and further enhance student interest in learning so that students have higher student learning outcomes. This is in line with Susilowati et al. (2017) which states that learning methods that are interesting and fun will make it easier for students to understand the material. Saputro (2016) also explained that by applying the role playing method students would be more interested in participating in learning activities.

Based on the results of the correlation test between the role playing method and student learning outcomes presented in Table 4 shows that both have a negative correlation with a low correlation and both have an insignificant relationship. Thus, it can be interpreted that the higher the student response to the role playing method, the lower the student learning outcomes. However, both have a low and insignificant relationship so the decision cannot be enforced in this study population. The response questionnaire contained several statements that showed students' responses after the application of the role playing method to several aspects, namely, interest in learning, student interest, learning atmosphere, learning experience, students' understanding of the material, curiosity, imaginative nature, challenges, and dare to take risks. Moreover, if the response score given is getting better then it can be interpreted that the student follows the role playing learning well so that it will further encourage the student to improve their learning outcomes. Therefore, in theory, the role playing method and student learning outcomes should have a positive relationship. That is, the higher the students' responses to the role playing method, the more they will improve student learning outcomes. However, the test results statistically show the opposite relationship. This is due to differences in the data collection method where the role playing method data is obtained by the questionnaire method while the learning outcome data is obtained by the test method. The questionnaire method and the test method have different strengths so that the data produced have different representations.

Even though calculations with statistics show a negative correlation, the results of the quantitative descriptive analysis have shown that the role playing method in learning the immune system is effective for improving student learning outcomes because it meets all the indicators that have been determined. The results of this study are in line with Anggraeni's (2015) study which concludes that the role playing method which assisted with Medispro is effective in improving student learning outcomes in the material of the human reproductive system. Sutiyani et al. (2015) also explained that the increase in student learning outcomes in the experimental class is higher than in the control class. Clorinda's research results (2018) about the influence of the role playing method also states that the application of role playing has an effect on improving students' learning outcomes.

\section{Implementation of Role Playing Learning}

The implementation of role playing learning in the learning of the immune system in the experimental class is taken from the results of the observation sheet of the implementation of learning which is filled by three observers. The results of the analysis of the feasibility of learning are presented in Table 5 . 
Table 5 Score of Role Play Implementation Learning

\begin{tabular}{|c|c|c|c|c|c|c|c|}
\hline \multirow[t]{3}{*}{ No } & \multirow[t]{3}{*}{ Statement } & \multicolumn{3}{|c|}{ Score } & \multirow{3}{*}{$\begin{array}{l}\text { Total } \\
\text { Score }\end{array}$} & \multirow{3}{*}{$\begin{array}{l}\text { Ideal } \\
\text { Score }\end{array}$} & \multirow{3}{*}{$\begin{array}{c}\text { Percenta } \\
\text { ge }(\%)\end{array}$} \\
\hline & & $1^{\text {st }}$ & $2^{\text {nd }}$ & $3^{\text {rd }}$ & & & \\
\hline & & Meeting & Meeting & Meeting & & & \\
\hline 1 & $\begin{array}{l}\text { The teacher gives an introduction to the material to } \\
\text { be studied }\end{array}$ & 3 & 3 & 3 & 9 & 9 & 100 \\
\hline 2 & The teacher explains how to implement role playing & 3 & 3 & 3 & 9 & 9 & 100 \\
\hline 3 & $\begin{array}{l}\text { The teacher prepares students who will play a role in } \\
\text { the role playing activities }\end{array}$ & 3 & 3 & 3 & 9 & 9 & 100 \\
\hline 4 & Students play the role well & 3 & 3 & 3 & 9 & 9 & 100 \\
\hline 5 & $\begin{array}{l}\text { Students who did not appear to observe the role } \\
\text { playing activities and noted important things }\end{array}$ & 2 & 3 & 3 & 8 & 9 & 88,9 \\
\hline 6 & Students are able to work with players & 3 & 3 & 3 & 9 & 9 & 100 \\
\hline 7 & Students are able to adapt in doing role playing & 3 & 3 & 3 & 9 & 9 & 100 \\
\hline 8 & Students are able to portray the character well & 3 & 3 & 3 & 9 & 9 & 100 \\
\hline 9 & $\begin{array}{l}\text { Students are able to take the initiative in doing role } \\
\text { playing }\end{array}$ & 3 & 3 & 3 & 9 & 9 & 100 \\
\hline 10 & $\begin{array}{l}\text { Students are able to express themselves according to } \\
\text { the roles they are delivered }\end{array}$ & 3 & 3 & 3 & 9 & 9 & 100 \\
\hline 11 & Students are able to be creative in role playing & 3 & 3 & 3 & 9 & 9 & 100 \\
\hline 12 & $\begin{array}{l}\text { The teacher and students clarify the material from the } \\
\text { role playing script that has just been demonstrated }\end{array}$ & 2 & 3 & 3 & 8 & 9 & 88,9 \\
\hline 13 & Students are active in group discussions & 2 & 2 & 3 & 7 & 9 & 77,8 \\
\hline 14 & The teacher evaluates learning activities & 3 & 3 & 3 & 9 & 9 & 100 \\
\hline 15 & The teacher and students draw conclusions together & 2 & 2 & 3 & 7 & 9 & 77,8 \\
\hline & Total Score & 41 & 43 & 45 & 130 & & \\
\hline & Ideal Score & 45 & 45 & 45 & 135 & & \\
\hline & Percentage $(\%)$ & 91,11 & 95,56 & 100 & 95,56 & & \\
\hline
\end{tabular}

Role playing learning is carried out in class XI MIA 2 for 4 meetings in accordance with the prepared lesson plans. The material discussed is immune system material with 4 subtopics, that are nonspecific immune system, specific immune system, immunization and abnormalities in the immune system. Classes are divided into 3 large groups and each group presents role playing in turns. Based on Table 5, it can be seen that the role playing method has been effectively implemented in learning the immune system material with a score of $95.56 \%$. The table shows that most of the learning stages have been carried out well.

Role playing activities begin with the preparation phase to prepare all the things needed in the implementation of role playing. Before performing, students are given the opportunity to prepare and practice with a group of friends. Scenarios and nameplates have been prepared by the researcher so that learning time can be used more efficiently. However, the researcher gives freedom to students to improvise the scenario here. At this stage, class conditions tend to be crowded and less conducive so that the role of the researcher is needed in assisting each group so that the exercise can run conducive. Students do many things such as studying scenarios, determining the players, learning the storyline, preparing all the needs in characterization (costumes and properties), memorizing dialogue and practicing group role playing. Meanwhile, the role of the researcher here is to help direct students to understand the role playing storyline and provide input in characterization. One of the strengths of the role playing method here is the direct involvement of students in each learning process. Students have direct experience in learning so that the impression obtained by students becomes stronger. Sutiyani (2015) explains that the existence of a strong impression can improve student learning outcomes.

Based on Table 5, students are able to work together and adapt to other players. The plot runs according to the scenario so the material can be conveyed clearly. The majority of students have dared to appear without reading the script so they have the proper appreciation and expression. In certain parts of the cast, three skin cells sing and dance with enough confidence. More than that, students are able to take the initiative and be creative in playing roles. This is indicated by the initiative to wear various costumes that support the roles played. All pathogens wear red robes and carry swords. This adds to their impression 
of being an evil role figure. The performance succeeded in attracting the attention of students to watch role playing from beginning to end even though there is some students who is still busy joking with friends beside them.

Immune system material is abstract material because it contains material concepts that cannot be seen directly with the sense of sight. Therefore, the use of the role playing method is very precise so that the abstract material concept can be visualized through role playing activities. The role playing method applied makes it easy for students to understand the material of the immune system because students are directly involved in playing certain plays which are a form of visualization of immune system material. This provides a direct learning experience so that the concept of material is easily accepted and remembered for a longer period of time.

The role playing is then ended and continued with the evaluation and clarification of the material from the role-playing that had just been witnessed. The researcher encourages students to comment on groups that have just appeared. One group representative commented that there are still some players who turned their backs on the audience so that it disturbed the focus of the audience. The researcher also comments that generally, all the players are able to play the role well, but there are still some students who is blocking and is not serious about playing the role.

The next activity is a group discussion to answer some questions related to the role playing material that has just been demonstrated. The information obtained while watching role playing is then processed and written to answer the questions on the discussion sheet. The results of the discussion are then delivered verbally by representatives of each group. At the end of learning the teacher tries to spur students to make conclusions from the learning that has taken place.

Based on Table 5 and the description above it can be stated that role playing learning has been carried out effectively because all stages have been carried out well even though it has not been maximized. Some deficiencies in role playing learning include: 1) at the first meeting, students are less active in making important notes when watching role playing, 2) students are less active in clarifying the material, 3) students are still less active in discussing and making conclusions. These deficiencies are caused by limited learning time so learning is not optimal.

\section{CONCLUSION}

Based on the results of research and discussion, it is concluded that (1) the role playing method in learning the immune system material is effective against the creativity of high school students, (2) the role playing method in learning the immune system material effective towards the learning outcomes of high school students and (3) the role playing method effective applied to the learning of the immune system material.

\section{REFERENCES}

Adiba, D.A., Susilowati, S.M.E. \& Yuniastuti, A. 2018. The implementation of role playing to improve students' cognitive activities and learning outcomes on excretion system in SMP N 1 Batang. Unnes Journal of Biology Education 7 (3): 237-243.

Anggraeni, L., Bodijantoro, F.P.M.H. \& Isnaeni, W. 2015. Efektivitas metode role playing berbantuan medispro untuk meningkatkan hasil belajar sistem reproduksi manusia. Unnes Journal of Biology Education 4 (3): 311-316.

Baroroh, K. 2011. Upaya meningkatkan nilai-nilai karakter peserta didik melalui penerapan metode role playing. Jurnal Ekonomi \& Pendidikan 8 (2): 149-162.

Clorinda, A., Sugiyono \& Rosnita. Pengaruh metode role playing terhadap hasil belajar siswa IPS Peserta Didik kelas V Sekolah Dasar. Jurnal pendidikan dan Pembelajaran Khatulistiwa 7 (9): 1-8.

Craciun, D. 2010. Role playing as a creative method in science education. Journal of Science and Arts 1 (12): 175-172.

Djamarah, S.B. \& Zaid, A. 2002. Strategi Belajar Mengajar. Jakarta: Rineka Cipta.

Jayanti, P., Hariani, D. \& Kuswanti, N. 2017. Validitas dan efektivitas LKS berbasisi pembelajaran aktif dengan metode bermain peran pada materi sistem imun. Jurnal Unesa 6 (1): 1-8.

Khoerunnisa, N. 2015. Optimalisasi metode bermain peran dengan menggunakan alat permainan edukatif dalam mengasah percaya diri anak usia dini. Jurnal Lentera 18 (1): 77: 91. 
Munandar, U. 2009. Pengembangan Kreativitas Anak Berbakat. Jakarta: Rineka Cipta.

Nurfaidah, Suprapta \& Said, M. 2018. Peningkatan hasil belajar dengan menggunakan metode pembelajaran student team learning modification. Jurnal Pendidikan Fisika 6(1): 26-30.

Oriza, A. 2018. Efektivitas metode bermain peran dalam meningkatkan kreativitas anak usia dini di taman kanakkanak al-khairiyah Labuhan Ratu Bandar Lampung. Skripsi. Lampung: Universitas Islam Negeri Raden.

Priyatno D. 2010. Teknik Mudah dan Cepat Melakukan Analisis Data Penelitian dengan SPSS dan Tanya Jawab Ujian Pendadaran. Yogyakarta: Gava Media

Rianto, M. 2006. Pendekatan Strategi dan Metode Pembelajaran. Malang: Departemen Pendidikan Nasional Malang.

Rumilasari, N.P.D., Tegeh, I.M. \& Ujianti, P.R. 2016. Pengaruh metode bermain peran (role playing) terhadap kemampuan berbicara pada anak kelompok A. E-journal Pendidikan Anak Usia Dini 4(2): 132-148.

Saputra, S. 2016. Pengaruh model pembelajaran discovery learning berbasis lingkungan sekolah terhadap hasil belajar siswa pada materi keanekaragaman hayati. Jesbio 5(2): 45-57.

Sudjana, N. 2009. Penilaian Hasil Proses Belajar Mengajar. Bandung: Remaja Rosda Karya.

Susilowati, S.M.E., Delima, A. \& Widyaningrum, P. 2017. Model pembelajaran problem based learning (pbl) berbantuan lks kreasi sistem respirasi untuk meningkatkan hasil belajar siswa SMA. Satya Widya 33(2):154-164.

Sutiyani, S., Nurhayati, S. \& Widiyatmoko, A. 2015. Pengaruh model pembelajaran role playing pada hasil belajar siswa SMP kelas VII tema global warming dan dampaknya bagi ekosistem. Unnes Science Education Journal 4 (3): 945-951. 